\title{
Regulatory B cell II- 10 production is diminished in juvenile dermatomyositis
}

\author{
Christopher Piper ${ }^{*}$, David Bending ${ }^{2}$, Hemlata Varsani ${ }^{2}$, Katie Arnold ${ }^{2}$, Lucy Wedderburn$^{2}$, Claudia Mauri ${ }^{1}$, \\ Kiran Nistala', Juvenile Dermatomyositis Research Group (JDRG) \\ From 21st European Pediatric Rheumatology (PReS) Congress \\ Belgrade, Serbia. 17-21 September 2014
}

\section{Introduction}

Juvenile dermatomyositis (JDM) is a childhood autoimmune disease characterised by proximal muscle weakness and cutaneous manifestations. Previous studies have identified an increase in circulating B cells in JDM patients, but their provenance and functional characteristics have not been examined. In this study we investigated whether an immature B cell subset (CD24 $\left.{ }^{\mathrm{hi}} \mathrm{CD} 38^{\mathrm{hi}}\right)$, known to be enriched for interleukin (IL)-10 producing regulatory B cells (Breg) ${ }^{\mathbf{1}}$, accounted for the expansion of circulating $B$ cells seen in JDM. The aryl hydrocarbon receptor (AhR) is a ligand based transcription factor, which induces IL-10 expression in $\mathrm{T}$ cells ${ }^{2}$. We investigated the effects of modulating the AhR pathway on IL-10 expression in B cells.

\section{Objectives}

- To characterise the peripheral blood B cell compartment in JDM patients with active disease and in disease remission (according to the PRINTO criteria).

- To test the capacity of B cells from JDM patients to produce IL-10 and ask if modulation of the AhR pathway alters B cell IL-10.

\section{Methods}

54 patients were recruited through the UK JDM Cohort and Biomarker Study. B cell subpopulations from peripheral blood mononuclear cells (PBMC) isolated from healthy controls $(\mathrm{HC})$ and JDM patients were analysed by flow cytometry using the surface markers CD19, CD24, CD38 and CD27. To detect B cell IL-10, PBMC were stimulated for 72 hours with CD40 ligand (CD40L) transfected $\mathrm{CHO}$ cells or the toll like receptor 9 agonist $\mathrm{CpG}$ (ODN 2006) +/- Ahr antagonist (CH-223191), together with PMA and ionomycin for the last 5 hours in the presence of Brefeldin A. Cells were then stained for CD19 and intra-cellular IL-10, which was detected by flow cytometry.

\section{Results}

PBMC from JDM patients with active disease had a significantly lower frequency of CD24hiCD38hi Breg when compared to inactive JDM patients (median of $7.6 \%$ vs $12.9 \%$ respectively, $\mathrm{p}=0.0109$ ). Active patients had a lower frequency of IL-10 producing B cells compared to inactive patients and child controls (mean of $12.1 \%, 15.8 \%$ and $18.6 \%$ respectively), but this was only observed following stimulation with CD40L and not CpG. Inhibition of AhR following CD40L stimulation augmented IL-10 production in JDM B cells, restoring it to normal levels. Blocking AhR had no effects on CpG induced B cell IL-10.

\section{Conclusion}

These data identify a reduction in Breg in JDM patients with active disease that was associated with defective CD40L induced IL-10, when compared to child controls. This defect was reversed following blockade of AhR. These results suggest that over-activity of the AhR pathway may contribute to the pathophysiology of JDM, by attenuating Breg function.

\section{Disclosure of interest}

None declared.

\section{Authors' details}

${ }^{1}$ Centre for Rheumatology, Division of Medicine, University College London, London, UK. ${ }^{2}$ Infection, Inflammation and Rheumatology Section UCL Institute of Child Health, University College London, London, UK. 


\section{References}

1. Blair PA, et al: CD19(+)CD24(hi)CD38(hi) B cells exhibit regulatory capacity in healthy individuals but are functionally impaired in systemic Lupus Erythematosus patients. Immunity 2010, 32:129-140.

2. Gandhi $R$, et al: Activation of the aryl hydrocarbon receptor induces human type 1 regulatory T cell-like and Foxp3(+) regulatory T cells. Nature Immunology 2010, 11:846-53.

doi:10.1186/1546-0096-12-S1-P86

Cite this article as: Piper et al:: Regulatory B cell II-10 production is diminished in juvenile dermatomyositis. Pediatric Rheumatology 201412 (Suppl 1):P86.

Submit your next manuscript to BioMed Central and take full advantage of:

- Convenient online submission

- Thorough peer review

- No space constraints or color figure charges

- Immediate publication on acceptance

- Inclusion in PubMed, CAS, Scopus and Google Scholar

- Research which is freely available for redistribution

Submit your manuscript at www.biomedcentral.com/submit
C Biomed Central 